\title{
SPATIALITY AND AGENCY: A PHENOMENOLOGY OF CONTAINMENT
}

\author{
KIRSTEN JACOBSON \\ University of Maine
}

It is easy to think of space as something outside and alien to us, as that which in its extension stands in contrast to the interiority of mind, feelings, point of view and other seemingly intangible aspects of subjectivity as regularly conceived in Western culture. In this essay, I challenge this dualistic and inward sense of subjectivity, demonstrating how integral space and spatial experience are to the very possibility and formation of ourselves as subjects i.e., beings with a point of view on others as well as on ourselves - and as agents - i.e., persons with choosing and meaning-making capacities. ${ }^{1}$ Indeed, I show that how we exist varies with how we inhabit space.

I am particularly interested here in how our agency is contained by space, but not in the sense in which water is in a pitcher. Rather than a limiting object, space is the extended situation in and through which our sense of self and choice becomes possible in the first place. This study of the interwoven character of personhood and spatiality coalesces with contemporary discussions of agency as interpersonal, situational, and, thus, ultimately heteronomous. Recognizing the constitutive spatial structures of our agency matters because these structures - precisely because of their heteronomy - can oppress the very agency they also constitute. In other words, there are existentially healthy and unhealthy forms of spatial containment that variably support or restrict the range and plasticity of our agency, and a failure to notice the importance of spatial experience leaves this aspect of our reality susceptible to neglect and abuse.

\footnotetext{
${ }^{1}$ As the essay proceeds, I will explain further what I mean by agency and health. Generally speaking, however, my sense of both of these aspects of human reality is that they are inextricably interpersonal and situational, and, thus, ultimately heteronomous. Throughout this essay, I will interchangeably employ the terms "subject," "self" and "person" as well as "subjectivity" and "personhood." While there are discourses that parse out the differences amongst these, for my purposes, I am trying to capture in these terms our reality as beings that experience themselves as having a meaningful point of view upon others and themselves.
} 
I begin the essay by considering the character of spatial experience and the implicit sense of ourselves that attends our embodied experience of space. I propose that our spatiality can be understood in terms of "containment," articulating how there are senses of both containing and being contained by space at the core of our experience. I will then examine how our senses of space and subjectivity develop hand in hand through our bodily practices of movement. This theme of movement will lead me to considerations of how the "containment" that is the inherent character of space can develop different forms of self-other experience and, thus, different experiences of agency. I will examine experiences in which space is explicitly noticed and felt as containment and, more specifically, as a hostile means of containment - namely, claustrophobia and two forms of imprisonment; these "case studies" will allow me to consider, respectively, how oppressive pressures on our agency affect our spatiality and vice versa. These analyses will underscore how our existential health depends in significant part upon the presence and cultivation of an appropriately supportive spatial environment. Overall, the essay will show how our formation as subjects is dependent upon the bodily-rooted and spatially articulated gestures through which we develop a lived sense of whether the world outside us is supportive and cooperative or hostile and threatening.

\section{A BRIEF PHENOMENOLOGY OF SPACE AS CONTAINMENT}

To set the groundwork for examining the critical role that spatiality plays in our makeup as subjects and existentially healthy agents, let us first trace a brief phenomenological description of spatial experience. ${ }^{2}$ Kant, a key forebearer of the phenomenological tradition, describes space as naming the meaningful form our experience takes. In any explicit experience of space, we are, according to Kant, implicitly experiencing ourselves; in other words, as an object of experience, space is "contained" in our subjectivity. But what specifically does it mean to identify experience as "spatial?" Kant writes, "[my] sensations [are] referred to something outside me ... [and I] represent them as outside and alongside each other" (2003, 68, A23/B38). Space is how I experience things as outside - as outside of me and outside of each other. Furthermore, "space is experienced as an infinite given magnitude": space is given in experience as "outside me" and as "infinite" (69, A25/B3940). Though "logically" our experience "contains" the meaning of space, Kant's description reminds us that the very meaning of space is that it contains us and it exceeds us infinitely. We experience space as that in which we are: we move about in space, perceive things in space, and find ourselves to be in space. In this sense, we experience space as containing us.

\footnotetext{
${ }^{2}$ For fuller phenomenological studies of the character of space, see Heidegger 1971; Husserl 1997; Jacobson 2006, 2009, 2010; Merleau-Ponty 2012; and Morris 2004. Ed Casey's The Fate of Place (1997) also offers an excellent history of changing conceptions of space and place across the history of Western philosophy.
} 
Space is also the opening in which we experience things as existing, appearing, and acting or being acted upon. A thing has its "room" or its "place" alongside others in a single shared medium. Yet, phenomenologically speaking and as already suggested in Kant's arguments, space is not a further "entity" beside the things of the world. Space is the coordinating context that provides the necessary distance for the emergence of things into independent and articulated appearing beings; and, reciprocally, it is through things in their detachment from each other that space is revealed to us. ${ }^{3}$ In other words, as Husserl (1997) describes in his 1907 lectures, Thing and Space, "[w] hat we see are bodies, and together with the seen, we grasp the 'between' . . . Thus space is . . co-seen" (223). By emphasizing that space is co-seen with things, Husserl also highlights that it is our grasping of the between, our co-seeing, that allows for the spatial array. As such, space is simultaneously the disclosing of our subjective articulation of being-in-the-world and that which we experience as holding us and things. Space is a contained-containing.

This co-seen and contained-containing character of space and things is readily recognizable in the context of vision: to see requires a "between" that separates and connects a viewer from the thing viewed, for a thing immediately atop the viewer fills the visual field to such an extent that all vision is blocked and without a viewer there is nothing to be seen. ${ }^{4}$ An infinitely complete consciousness, as Husserl proposes, could not have "a" view on things or space; it would be completely filled in and, thus, have no room for appearance $(1997,98)$. Similar structures exist for other sense modalities. Hearing requires a resonating medium through which the vibrations produced by one thing can reach across and be "felt" and heard by a listening being; smelling occurs only if some scent can unfurl itself from a there to our perceiving here; touch implies the ability for a feeling being to work its way along the texture of a thing; and taste involves a similar working through and noticing the flavors of an opposing surface. Merleau-Ponty writes: "We are thus justified in saying a priori that all of the senses are spatial, and the question of knowing which sense gives us space is unintelligible, provided we reflect on what a sense is" (2012, 226). Space is the necessary context of possibility without which appearing and, thus, "experience $\rho$ " and "reflection on" would be impossible.

As the arena of juxtaposition, space is also the containing field wherein a change from the self-identical can be made. For instance, we require a surrounding open that can be entered if we are to be able to do anything. Further, Husserl argues that for something to appear as a distinct thing, there indeed must be movement $(1997,85)$. Without movement, there would be a flat and filled visual field - if it could even be called that - in which nothing could appear as discreet: a completely full and depthless sheath would accost our "view." Motion reveals what holds together in a unity and what falls apart as distinguishable, and

\footnotetext{
${ }^{3}$ For an excellent discussion of an object's possession of a spatial background, i.e., of being inextricably wound up with a background, see Ahmed (2006), especially pp. 548-9.

${ }^{4}$ Merleau-Ponty (1968) offers an arguably deeper discussion of this "between" in his articulations of the notion of flesh in "The Intertwining - the Chiasm." For related discussions of depth, see Casey (1991) and Merleau-Ponty (1993).
} 
through our experience of things as things, we can notice and have the sense of the space in which these things are independent from their surrounding field. Space must be present for things to exist, but it is only in movement that this space and the things within its fold are able to be experienced (Morris 2004). ${ }^{5}$ Movement is, thus, a prerequisite for our ability to encounter space as space. Moreover, inasmuch as spatial distancing is the precondition of appearance as such, it is our embodiment and our ability to move - in whatever variable expressions this may occur - that make experience as such possible.

These productive and grounding aspects of movement underscore the character of space both as arising through our containing activity and also as that which is experienced as what contains us and gives our activity a field of range and reference. As Heidegger (1962) describes, we do not initially experience the spatial world as an optional, objective content of experience but rather as the inescapable practical setting in which our lives unfold: we exist as being-in-the-world. ${ }^{6}$ Phenomenologically, space is not initially an indifferent arena, but rather the place of containment that is our manner of existing, the setting intrinsically connected with our being-at-home in-the-world. ${ }^{7}$

\section{SPATIALITY, MOVEMENT, AND AGENCY}

With this phenomenological backdrop of the containing-contained relationship of space and subjectivity, I turn now to consider how our experience of agency is tied up with our spatial situation. More specifically and following the thrust of the arguments above, I will examine research that shows how space functions as the home or situation in which our choosing and meaning-making capacities become possible in the first place, and how this very relationship can foster or inhibit our existential health.

Let us begin by considering phenomenological conceptions of motor intentionality and agency in Husserl (1989) and Merleau-Ponty (2012). Both argue that the original experience of oneself is not an "I think" but an "I can" - that is, a lived sense- revealed in

\footnotetext{
5 " [T] he constitution of the Objective location and of Objective spatiality is essentially mediated by the movement of the Body, or, in phenomenological terms, by kinaesthetic sensations" (Husserl 1997, 148, 198). For a good, contemporary account of motor intentionality, see Evan Thompson's Mind in Life: Biology, Phenomenology, and the Sciences of Mind (2007), especially pp. 247-49 and pp. 312-17.

${ }^{6}$ Heidegger's Being and Time (1962) begins with a relevant description of our reality as "being-in-theworld" (sections 12-14). Merleau-Ponty (2012) studies these different conceptions of space under the headings of the abstract "spatiality of position" and the concrete "spatiality of situation" in the chapter entitled "The Spatiality of One's Own Body and Motility" in Phenomenology of Perception. Note that neither Heidegger's nor Merleau-Ponty's accounts of space necessitate that we experience our spatial situation as nice, kind, or "homey" even if it is our familiar "ground" (Jacobson 2006, 2009, 2010).

${ }^{7}$ For further discussions of the existential characteristics of home, being-at-home and dwelling, see both Heidegger (1971) and Jacobson (2009, 2010).
} 
practice - of one's ability to act. " $[\mathrm{M}] \mathrm{y}$ body," Merleau-Ponty writes in the Phenomenology of Perception, "appears to me as a posture toward a certain actual or possible task" $(2012,102) .{ }^{9}$ Said otherwise, we are fundamentally practical subjects, and the spatial world is fundamentally experienced as the arena for our possible action. ${ }^{10}$ For example, if my aim is to join a gathering on an upper floor of a building, I do not typically notice "a set of stairs" in a reflective manner since I experience the possibility - or even the imperativeto climb them, and my body conforms itself to the stairs as if drawn through them to its destination. ${ }^{11}$ The thing is experienced as a summons to action and my living body is experienced by me as my capacity to respond. ${ }^{12}$ Both experiences are inextricably spatial and agential.

Empirical research on the development of conceptions of space in children supports the phenomenological arguments that spatiality is tied up with our bodily abilities as well as our sense of agency. ${ }^{13}$ The stage-setting psychological studies of Piaget and Inhelder (1956)

${ }^{8}$ See Husserl 1989, 13-17, 159-69, 226-31, and 266-80; and Merleau-Ponty 2012, 139-40. Compare Noë 2004, 63.

${ }^{9}$ Thompson and Zahavi (2007) bring out the relationship between this "I can" and our earlier reflections on the motor-revelation of things and space: "If something appears perspectivally, then the subject to whom it appears must be spatially related to it. ... To say that we perceive only one profile of something while being aware of other possible profiles means that any profile we perceive points beyond itself to further possible profiles. Yet this reference of a given profile beyond itself is equally a reference to our ability to exchange this profile for another through our own free movement (tilting our head, manipulating an object in our hands, walking around something, etc.) ... One's lived body is not co-given as an intentional object, however, but as an implicit and practical 'I can' of movement and perception” (79).

${ }^{10}$ Compare Heidegger (1962) on the idea that affectivity (Stimmung [mood]) and Befindlichkeit [state of mind] are at the basis of our experience - our self-consciousness begins in how we experience things their emotional colouring - rather than in a direct reflection upon ourselves (sections 28 and 29). See also Leder's (1990) discussion of the way mood shapes our experience (84-5).

${ }^{11}$ On this "summons" from the object, see Husserl (1989): "The Object, as it were, wants to be an Object of advertence, it knocks at the door of consciousness . . . it attracts, and the subject is summoned until finally the object is noticed. Or else it attracts on the practical level; it, as it were, wants to be taken up" (231). Compare Merleau-Ponty (1963, 168-69). The strength of this call may even "overwhelm" a person's intentions. For instance, someone may pass an exit on a highway where she intended to get off because what Merleau-Ponty (2012) calls her "habit body" has continued on to a more regularly taken exit (84-9, 140-48, 288); an impressive cathedral may quiet and subdue an otherwise voluble and energetic person; crowds of people are shown to move in regular sine wave sequences of motion when under certain types of situationally-induced pressure; and, architectural features ranging from shape to color are shown to affect productivity, mood, the intensity and even possibilities for human action (Moussaild, Helbing, and Theraulaz 201 1; Profusek and Rainey 1987; Tuan 1974; and Valdez and Mehrabian 1994).

${ }^{12}$ For related discussions of agency see Jacobson 2017; Jacobson and Russon 2018; Laing 1969; and Russon 2003, 2009.

${ }^{13}$ Further research also shows that spatial development in infants around twelve months of age develop in relationship with their abilities for self-movement. Tracking behavior and object location in the infants were stronger in those infants who moved themselves. The researchers concluded that "self-produced movement appears to aid the infant by increasing attention to relevant environmental information" (Acredolo, Adams, and Goodwyn 1984, 324). They noted that their results could equally be a sign that being moved by adults, rather than by themselves, could in fact hinder tracking ability. 
revealed that conceptions of space do not follow simply from the mere perception of things in space. Rather, children develop an understanding of and relationship with space through being involved in and learning new activities - such as being able to grasp an object, move an object, arrange objects, and so forth $(1956,25,41,449,454) \cdot{ }^{14}$ Kermoian and Campos (1988) conducted related studies testing the relationship between infants' capacity for locomotion and their spatial search performance. The tests involved attracting infants' attention to a toy of interest and then concealing it to a variety of degrees. Sometimes the toy was partially concealed; other times it was placed under one of two identical cloths; still other times it was hidden under multiple cloths; and sometimes a delay occurred between placement and when infants were allowed to begin searching for the toy. The experiments were carried out with varied trial set-ups to study different levels and aspects of infant locomotion. The results overall showed that infants' ability to search successfully for an object of interest is connected to their specific capacities for locomotion. For an infant to attain the highest results on the given search tasks, locomotion needed to be self-motivated and on hands and knees. Infants who could not yet crawl but could move "artificially" in rolling walkers did not achieve the levels of spatial development possessed by self-locomotive infants; they did, however, show greater capacities to attend to external objects than pre-locomotive infants and belly crawlers (915). Locomotor-limited children did not gain the search abilities under study simply due to the passage of time; rather, any increase in being able to locate a desired object arose only as relevant locomotive skills were developed (915). These experiments demonstrate that locomotion has functional consequences for spatial search abilities; in other words, locomotion facilitates the development of children's abilities to seek out and find an object set apart from themselves in a complex spatial array (914). These results correspond to the developmental studies of Piaget and Inhelder that demonstrated that to achieve a generalized spatial schema - i.e., a spatial system of integrated positions, regular

\footnotetext{
14 Core aspects of Piaget and Inhelder's (1956) interpretation of human spatial experience differ notably from phenomenological accounts, such as those given by Merleau-Ponty. To a large extent, they present their developmental picture of spatiality as one in which the developmental endpoint of spatial understanding is the "achievement" of the Euclidean perspective. Not only does Merleau-Ponty question the weight placed on "spatial objectivity" by this account, but he also argues that the child's experience of space - even as Piaget and Inhelder describe it - contains important resemblances to the nature of adult spatial experience; in other words, as we have already begun to see in our analyses, adult spatial perception proves to be far less Euclidean-like than Piaget and Inhelder suppose (see also Merleau-Ponty 2012, 317-8, 415-5). Moreover, Piaget and Inhelder focus on the child's "conceptual" experience of space as the site for examining spatial development, whereas Merleau-Ponty locates the source for examining spatial experience - both developmentally speaking and otherwise - as lying in the realm of perception. In spite of these differences, the analyses of Piaget and Inhelder significantly support Merleau-Ponty's argument insofar as they demonstrate the connection between spatial levels and the body's abilities and activities. My analysis of Piaget and Inhelder's argumentation regarding the body and spatial development may, in fact, serve to moderate certain criticisms of their work leveled by or implied in Merleau-Ponty's philosophy.
} 
distances, fixed dimensions, and so forth - children must first develop the ability to perform activities that would correspond to - and make possible - such a view of space $(1956,193) .{ }^{15}$

Research has also shown that experiences of movement help to reveal us to ourselves and set up conditions that allow us to experience ourselves as agential beings. As we began to see above, movement is crucial for the development of outward awareness; it is also critical in stimulating developing forms of awareness of self-other juxtapositions. For instance, in contrast to premotor infants, infants with some form of locomotion react at a notably greater cardiac level when exposed to an experimental cliff edge; are more capable of picking invariant structures out of a mixed display; and demonstrate greater interest in surrounding social stimuli and unknown adults. ${ }^{16}$ Gerardi-Caulton demonstrated a correlation between the ability of young children to perform spatial tasks and "their ability to shift attention between activities, focus attention effectively, and pay attention to subtle stimuli in the environment"- components of attention that the researchers connect with a child's capacity for self-regulation $(2000,403)$. These activities show nascent signs of infants either doing something of their own accord or reacting to something or someone as distinct from themselves. Such shifts toward reflectivity mark a critical step in opening onto a spatially thick and diversified reality as opposed to the "pre-reflective and unmediated" space of infancy in which Eva Simms describes the infant as "inserted into the flesh of the world" (2001, 34-35). ${ }^{17}$ As such, these spatial steps - both literal and figurative - mark a crucial stage when an infant begins moving out into and engaging with what is other.

In contrast, Simms (2014) discusses how infants whose early life is spent without significant interactive contacts with other human beings (as has occurred in the past in significantly under-supported "foundling homes" or orphanages) will fail to emerge from an inner world of solipsism (85). Based on a variety of evaluations, observations and testimonies, Simms describes the roots of the contracted existential reality of a particular child, whom she calls Rudy, who was "raised" in such an orphanage. In his infancy, Rudy lived in an environment in which an absolutely bare minimum of human contact was given; he was not permitted to move beyond the site of his crib. His initially given surroundings were thus limited to a fairly static set of perceptual possibilities that, additionally, were neither described nor manipulated in significant or novel ways by adults. Although Rudy's

\footnotetext{
15 Piaget and Inhelder (1956) identify a developmental pattern for the child's changing conception of space - one that moves from the topological to the projective and, finally, to the Euclidean - and they ascribe this development directly to the child's development in her abilities to accomplish various tasks related to motion, arrangement and organization, rotation, drawing, etc. (419).

${ }^{16}$ Relevant studies cited in Kermoian and Campos (1988).

${ }^{17}$ Simms's (2001) argument in "Milk and Flesh" emphasizes that this original immersion in the world is a dyadic one - typically of mother and infant - but not a "dyad" experienced by the infant as dualistic or reflective in any way. Indeed, Simms's argument helpfully articulates the character of our foundational pre-reflective spatial experience that Maurice Merleau-Ponty describes vis-à-vis the infant in "The Child's Relations With Others" (1964) and vis-à-vis adults in the Phenomenology of Perception (2012) (in terms of "situated space") and in "The Intertwining - The Chiasm" (1968) (in terms of "flesh"). See also Bredlau 2008, 2010.
} 
capacities for engagement and world-expansion were in principle developing as his body grew, these capacities were never encouraged or supported by his nominal care givers at the orphanage. Even after his adoption (at eighteen months of age) and in subsequent childhood years, Rudy's world carried the traces of the significant constraints in the spatial reality of his early years. Simms reports:

When Rudy is evaluated at the age of three years and two months, he is easily overloaded by sensations and has trouble focusing; he shows tactile defensiveness and squirms away when his [adoptive] parents touch him; he drops things all the time and cannot discriminate shapes and textures with his fingers; he constantly crashes into things, even big things like chairs and cars because he does not know where they are in relation to his body and where his body is in space (proprioception), and because he easily loses his balance . . . $(2014,82)$

As noted above, Simms locates the crux of the contraction in Rudy's world-engagement as a lack of early "intimate" engagements by others. What is striking for the current argument is the fact that Rudy's lack of interpersonal engagements at a young age has impinged simultaneously on his spatial and agential experiences. As Simms notes:

The world is a panorama spread out before him and does not break though the wall of his solipsism. It does not reveal to him his own transcendence but only his insertion into the flow of perceptual events. He is . . caught up in the tacit meaning on the surface of the world. (85, emphasis added)

Though Rudy notices elements of his surroundings, he does so ". . . without ever having any real distance from them. He is completely submerged in his familiar perceptual world. He is held hostage by the very fact that we are perceptual beings" (85). Agency, movement and spatiality are simultaneously contracted in Rudy's experience. ${ }^{18}$ Said otherwise, Rudy's experience in infancy has altered the reach of his embodiment of the surrounding world, limiting the plasticity of his forms of being-in-the-world.

In describing Rudy's experience of agency as contracted in this way, I am not indicating that he possesses a lesser degree of agency. People's bodies and capacities pointedly differboth from one another's and even across one's own life trajectory. The co-defining relationship of body and world can also be more or less supported for particular people as

\footnotetext{
${ }^{18}$ Psychologists D.W. Winnicott (1971) and R.D. Laing (1969) similarly write about the intrinsic connection between the young child's outward moving developments and a sense of familial or ontological security, respectively.
} 
well as more or less thetic at varying times in persons' lives. For instance, spatial settings that are designed for those who can walk without assistance can and often do set up challenges or prohibitions for those who need a wheelchair or walker to move. Even though various experiences of illness or disability may be challenging or may limit a person from certain activities, and may also indicate signs of a failing of society to support or address varying bodily capacities, in every case, people are working from the situation of their particular embodiment and the affordances of their surrounding environments. As Sharon Krause has argued:

... while the selfhood that figures in agency is robust, it should not be understood as singular or fixed or essential. Every self is something of a plurality containing multiple strands, some of which may sit uneasily with one another. Moreover, because we exist in dynamic relationship with our social and material environments, we are all subject to change. None of us remains perfectly identical over time. And because our characters evolve in connection with our changing circumstances, it would be wrong to think that any particular feature of our subjective existence constitutes an a priori essence. $(2015,22)$

The argument of this essay has built towards underscoring the recognition that each of us develops agency - our "I can" - as our particular bodies engage with and through our surrounding environments. Pointedly because this "I can" is not a given facticity of our existence, it can vary and also shift. For instance, phenomenological authors such as J.H. van den Berg (1966), Isabel Dyck (1995) and S. Kay Toombs (1987) have attended carefully to experiences of chronic illness, describing the significantly intertwined changes of persons' dynamic "I can" and their experiences of the surrounding world and the things within it as illness waxes or wanes. In Psychology of the Sickbed, van den Berg describes how the experience of the acutely ill person reflects a lagging "I can" in the form of things and even people becoming unfathomably distant and irrelevant. Imagining the experience from within, he writes: "The world has shrunk to the size of my bedroom, or rather my bed. For even if I set foot on the floor it seems as if I am entering a terra incognita" (1966, 26-27). Toombs emphasizes the depth of this foundation-loss in chronic illness: "The familiar world, including the self, is suddenly perceived as inherently unpredictable and uncontrollable" (231). A flare up of multiple sclerosis symptoms can, for example, cause an environment that is typically smooth and unnoticed by a person to come painfully and disruptively to the fore, demanding that it be dealt with before the person's other intentions can be pursued (Dyck 310-312). Toombs concludes that chronic illness strikes at the essential cores of lived experience, leading to ". . . the perception of loss of wholeness and bodily integrity, loss of certainty and concurrent apprehension or fear, loss of control, loss of freedom to act in a 
variety of ways, and loss of the hitherto familiar world" (234). ${ }^{19}$ Such examples underscore the dynamic relationship between agency and spatial experience. ${ }^{20}$

In this essay, I have been focusing on how agency can and will be differently articulated in coordination with our changing spatial circumstances. Spatial arenas in which we experience persistent resistance or frustration may be ones in which we need interpersonal or therapeutic support of some sort; they may also be sites in which we are being oppressed by other persons or existential and political structures. ${ }^{21}$ In the next section, I will consider spatial settings that are explicitly experienced as sites of oppressive containment. This final and most pointed study of space as containment will provide tangible examples of the argument that existentially healthy agency is not the guaranteed lot of all persons by nature, but, rather, becomes possible only if we are properly nurtured within and by our interpersonal and cultural settings. In other words, "healthy" or "unhealthy" agency is not rooted in given and fixed capacities, but rather quite significantly in whether our abilities to engage creatively and responsively with our situation are supported or oppressed by our surrounding reality.

\section{WHEN SPATIALITY BECOMES AN EXISTENTIAL PRISON: CASE STUDIES OF INTERPERSONAL ENGULFMENT AND TORTUROUS IMPRISONMENT}

We have seen above how our experiences of agency are connected to a sense of being contained by space in such a way that we feel sufficiently able to explore and shape meaning for ourselves, to have a spatial home, so to speak. In other words, the "I can" of the developing child occurs hand-in-hand with a developing sense of being-at-home-inthe-world. For instance, we saw that an infant's movements begin to be made outward as other foundations become more secure; the infant explores unknown objects and people only upon feeling grounded in new bodily capacities; and, by contrast, an infant raised in impoverished interpersonal circumstances will fail to be able to do either of these at age appropriate levels. I want now to consider experiences in which our inescapable spatial

\footnotetext{
19 Fredrik Svenaeus (2011) also emphasizes the intrinsic connection between illness, embodiment and one's spatial experience: "Illness is an unhomelike being-in-the-world in which the embodied ways of being-in of the self (person) have been thwarted. In illness the body shows up as an alien being (being me, yet not me) and this obstruction attunes the entire being-in-the-world of the ill person in an unhomelike way" (337).

${ }^{20}$ For further studies of shifts in spatial experience relating to differing bodily capacities, see Carel 2008; Charmaz 1983; Honkasalo 2000; Jacobson 2004, 201 1, 2017; and Leder 1990, 2004.

${ }^{21}$ For instance, both van den Berg (1972) and Russon (2003) argue that mental health challenges such as "neurotic" or compulsive behaviors mark certain ways of being-in-the-world that are typically experienced directly or indirectly as frustrating or closing down certain actions or possibilities for that person. Both authors also see other people (or other human resources such books, art, or therapeutic programs) as key to supporting a person in developing greater plasticity in those existentially contracted arenas.
} 
setting is explicitly experienced as one in which a person feels trapped or imprisoned. By looking at breakdowns in spatial inhabitation, we will see more deeply into the dynamic connection between spatiality and agency. While the fundamental intertwinement of expressions of spatiality and agency has already been made emphasized in this essay, we will now examine the dynamic bidirectional relationship of these existential aspects of our reality by considering through cases of interpersonal engulfment how pressures on one's agency can lead to inhibited experiences of spatiality and, then, through cases of torturous imprisonment how restrictions on one's spatial setting can lead to inhibited forms of agential expression.

When we feel trapped, we can lose the sense of ourselves as independent and become consumed by our setting. In illness, as noted above, the body is not an inconspicuous platform for action but becomes a conspicuous obstruction that forces itself upon our attention. ${ }^{22}$ We can understand our founding relationship to space along parallel lines. A troubled affective sense of home can become existentially consuming, making free engagement with the world impossible. I have argued elsewhere, for example, that this is how we should understand the experience of agoraphobia: the agoraphobic is so threatened by what is other that openness to exchange with the outside becomes intolerable (Jacobson 2004, 2011). Research has shown that this experience of threat is regularly rooted in the agoraphobic's lack of a secure sense of home, itself the result of early interpersonal experiences of not being supported in the development of the agential capacities that pertain to our free action (2004). Without a secure and supportive home base, the agoraphoic finds encounters with what is 'other' to be dangerous rather than liberatory, self-defeating rather than self-defining, sites of abandonment rather than of opportunity. To avoid this conflict, the agoraphobic often remains "at home." Yet this "home" is equally traumatizing even if it seems easier to deal with. It is an imprisoning form of containment, rather than a supportive home base from which she can emerge to engage with the world. Her experience of space, whether at home or beyond, is one of exile or threat. ${ }^{23}$

We see this experience of imprisonment arise perhaps even more pointedly in claustrophobia - a disorder whose main symptoms are a sense of trappedness, suffocation, and loss of control (Febbraro 1995, 349; Shafran el al. 1993). The psychoanalyst W.R.D. Fairbairn identifies the origins of claustrophobia in the developmental struggles between identification with others and independence from others - struggles that occur especially in the transitional stage between infantile and mature dependence (Willoughby 2001, 921). Fairbairn maintains that the self oscillates "between fears of engulfment or confinement and [fears of] isolation, or between claustrophobia and agoraphobia" (921). The claustrophobic

\footnotetext{
${ }^{22}$ This language of the body (and the home) as "platform" is from John Russon (2009, chapter 1). The language of the "inconspicuous" and the "conspicuous" is from Heidegger (1962, section 16).

${ }^{23} \mathrm{On}$ the theme of the hostility of the home space vis-à-vis agoraphobic and claustrophobic experience, see also Trigg 2017 (especially chapters 1 and 2) and 2018.
} 
aspect of the self is that which feels vulnerable with respect to other people to whom it is attached; specifically, the claustrophobic person worries specifically that she will be trapped with this person. ${ }^{24}$

Laing's (1969) existential psychology offers a helpful elaboration here of the crucial role of other persons in our establishing a sense of home. Laing argues that the development of a lived sense of oneself as an independently real agent is accomplished only through the interpersonal support through which others communicate their recognition of our independence. ${ }^{25} \mathrm{He}$ describes engulfment as one characteristic way that others - typically parents - may hinder another's developing sense of autonomy. For the engulfed person, the interpersonal world is experienced as a smothering containment in which one is allowed no room for independence and self-expression, and the only viable behavioral option is "escape":

The main manoeuvre used to preserve identity under pressure from the dread of engulfment is isolation. ... [1]nstead of the [healthy] polarities of separateness and relatedness based on individual autonomy, there is the antithesis between complete loss of being by absorption into the other person (engulfment), and complete aloneness (isolation). There is no safe third possibility of a dialectical relationship between two persons, both sure of their own ground. (Laing 1969, 44, emphasis added)

In the experience of interpersonal engulfment, containment is not experienced in a way that "makes room" for the individual. Home has become a site of threat to one's independent individuality rather than an enabling site of one's agency. According to the psychological accounts addressed here as well as the larger argument of this essay, the foundation of a claustrophobic experience of the world can be described as rooted in a form of containment that structures one's way of being-in-the-world as inherently inhibiting.

This analysis of an interpersonal home environment that does not allow room for one's individuality to be recognized dovetails with Raymond H. Gehl's (1964) argument that the claustrophobic response marks a struggle in the development of one's decision-making and action-oriented powers such that a person feels trapped inside herself. According to Gehl, what the claustrophobic sees in the frightening spatial surroundings is her own fright in the face of taking up the powers to act, to distinguish herself from others, and to feel capable

\footnotetext{
${ }^{24}$ Fairbairn analyses this in terms of the "primary attachment object," which can also "through projective identification into the environment" be a tangible thing rather than a person (Willoughby 2001, 921, citing Fairbairn).

${ }^{25}$ Russon and Jacobson (2018) make a related argument regarding the significance of interpersonal relationships for the development of one's existential health and overall ability to engage with and in the world.
} 
of being present in a situation with another person without being overwhelmed. ${ }^{26}$ Our lived, affective sense of containment - the primordial meaning of our spatiality - is thus fundamentally a matter of navigating our interpersonal boundaries, or, said otherwise, of our experience of participating as individual agents in an interpersonal world.

The meaning of our spatiality is that we are thrown outside ourselves, and thus into the field and care of an interpersonal world. ${ }^{27}$ The experience of claustrophobia reveals that the roots of our ability to live as agents is interwoven with how others serve to shape our experience of containment - namely, in an enabling or disabling way. Our experience of ourselves as "autonomous" agents is actually one of heteronomy: we are vulnerable to our experiences of containment, and it is in our formative experiences with interpersonal others that our spatialized sense of agency is initially cultivated. As a mirror image to this portrayal of a troubled interpersonal cultivation of agency, I will now consider how an experience of agency can be broken down through experiences of unhealthy spatial containment that is more pointedly physical or structural.

In the case of incarceration, there are certainly elements of interpersonal effects on one's agency and sense of space. Additionally and notably, however, we also find here physical spatial effects shaping one's experience of agency and interpersonal capacities (Guenther 2011, 2013; Leder 2004, 2016). ${ }^{28}$ It is obvious that imprisonment is a form of containment that intentionally limits an agent's ability to move about in space. The limitations imposed by incarceration, however, are much greater than this. Though imprisonment seems at first only an "external" limitation that leaves the person intact, we will see through two extreme examples that in fact the experience of containment in imprisonment can bring about severe and troubling existential changes in imprisoned persons. ${ }^{29}$

The relationship between one's sense of self and one's spatial situation is seen clearly in a particularly severe form of imprisonment that emerged in the United States penitentiary system in the 1980s: the "supermaximum custody unit" (Haney 2003, 128-29). Persons imprisoned in "supermax" units are confined in a small cell of roughly 6 by 8 feet with a solid steel door as its only opening; their lighting often remains on 24 hours a day, and is not controllable from within the cell; they are released from the cell only a few hours per week for private exercise in a "dog run"; often upon release for these activities, the incarcerated

\footnotetext{
${ }^{26}$ Multiple studies of claustrophobia have found direct connections between the feeling of inefficacy in the face of external threats and the development of anxiety (Bandura 1988; Bolte 1996, 608-10; and Valentiner, Telch, and Petruzzi 1996).

27 Thrownness (Geworfenheit) is a constitutive feature of Dasein, according to Heidegger's (1962) phenomenological description in Being and Time (sections 28, 31, and 38). See also Drew Leder's (1990) chapter "The Ecstatic Body" in The Absent Body for an insightful discussion of examples of how we are "thrown" beyond ourselves in our daily existence.

${ }^{28}$ I am particularly grateful to the work of both Drew Leder and Lisa Guenther for their insights on the topic of imprisonment and issues of space, agency, and mental health.

${ }^{29}$ See Ahmed (2018) for a related discussion of the existential spatial constrictions arising from drone surveillance technologies.
} 
person is first tethered from outside of the cell by a leash and eventually placed in multiple restraints; finally, their interaction with other inmates and even staff is severely limited, and visits from others, when permitted, are typically conducted through closed-circuit television or teleconference (Arrigo and Bullock 2008, 624-25, 628; Haney 2003, 126). In this situation of imprisonment, the incarcerated person's spatial situation is transformed into one in which meaningful engagement with the world and others is eliminated. As our argument thus far would lead us to expect, empirical research has concluded that "there are few if any forms of imprisonment that appear to produce so much psychological trauma and in which so many symptoms of psychopathology are manifested" (Haney 2003, 124). ${ }^{30}$

Craig Haney identifies characteristic pathologies developed by persons in supermax confinement - all of which indicate that extreme contraction and impoverishment of one's spatial setting can lead to the contraction and impoverishment of one's fundamental experience of agency. Haney reports that persons existing in supermax imprisonment develop problems with self-initiation and self-control of their behaviors; lose the ability to follow through on even simple goal-oriented tasks; lose a clear sense of who they are and how they might fit into the world; withdraw from any possibilities to develop interpersonal relationships or their grounding in the world, reverting instead to a fantasy world from which they do not seem able to emerge; and, lastly, develop experiences of "intolerable frustration," which may develop into rage that often erupts in behaviors that increase the amount of time they will be forced to spend in the very conditions leading to their frustration. In short, we see that the supermax-incarcerated person shows signs of losing almost entirely their self-defining and other-relating capacities.

The "frequent flyer program" used at Guantanamo Bay, which involves moving detained persons from cell to cell such that they experience significant sleep deprivation and disorientation, shows similar existential effects. Here, by not allowing a person a place to "settle," the spatial situation becomes an aggressive container, and space is itself used as an attack on one's very way of being-in-the-world. In the words of the U.S. military, this technique is used "to soften detainees for subsequent interrogation" and "to profoundly disrupt [the person's] mental senses" (Frakt 2011; United States v.Jawad 2008, respectively). ${ }^{31}$ In both supermax imprisonment and in the "frequent flyer program," what begins as an externally imposed spatially restrictive regime ends up structuring the very shape that the agent is able to give to the world.

These situations of torturous imprisonment as well as those we examined above of interpersonal engulfment are, then, sites of interpersonal contact that cultivate a disabling experience of containment rather than a healthy space of being-at-home, and as such, they inhibit the formation of a healthy experience of agency. In doing so, they precisely reveal

\footnotetext{
${ }^{30}$ Research on this point is extensive and highly conclusive (Grassian 2006; Grassian and Friedman 1986; Guenther 2013; and Jackson 1983, 2001).

${ }^{31}$ See White (2008) for further description of the "frequent flyer program."
} 
the vulnerability of our agency to our lived experience of spatiality. Similar to the effects we saw earlier in Simms's (2014) account of an infant raised in impoverished interpersonal circumstances, cases of extreme psychological or physical confinement demonstrate that - even in adulthood - our agency is not something that belongs to an individual alone; rather, it is interwoven with our setting as well as with other persons. Human agency is always dialogic - i.e., a situated, relational, and creative shaping force of reality.

\section{CONCLUSION: CARING FOR PEOPLE INVOLVES CARING FOR SPATIALITY}

This essay has emphasized how human experience involves the definitive capacity of being "freed up" with respect to our surroundings, of existing as liberated from space such that we can give meaning to our situation according to explicit and implicit choices either independently or with the cooperative support of others. In this sense, we experience space as an open place in which our possibilities can unfold. Yet, even though the experience of a separate but responsive world is a distinctive mark of the experience of agency, our phenomenological reflections have also shown that our paired experiences space and agency are developed. And, while as human beings we cannot avoid being confronted by agency, its development is not "perfectly" secured. Our experience of space as the site of our existential containment varies with our own situational and personal wellbeing: our specific experience of ourselves as agential subjects is correlated with a distinctive form of spatial experience that is always already defined with and through what is other.

Recognizing that we are dependent on the support of others and on our surroundings in this way does not detract from our agency. Rather, the argument of this essay aligns with contemporary claims that we live by means of a "relational autonomy" or "situated agency" - that is, that we are always already intertwined with others and that our agency emerges from our determinately situated existence. ${ }^{32}$ Indeed, the notion of agency as autonomous fails to capture our lived experience. As Kristin Zeiler argues:

While the term autós has come to refer to one's own or one's own self in discussions of autonomous choices as choices made by self-governing individuals, the phenomenological reasoning on the embodied self as being-in-the-world and the embodied self as intercorporeally formed allows for an acknowledgment of how someone's "ownness" is intrinsically bound up with various dimensions of otherness. Not only are embodied subjects formed in relations over time, but subjectivity and agency are also thoroughly dependent on the larger situation in which they are articulated. (2018, 98-9)

\footnotetext{
${ }^{32}$ For relevant discussions of the intertwined and situated character of our autonomy and agency, see Jacobson (2004, 2009), Russon (2003), and van den Berg (1972). See also Slatman, Zeiler, and Devisch (2016) for their discussion of the autonomy of the bodily self as always already heteronomous (18-19).
} 
María Lugones underscores the danger of what she calls "the fiction of effective individual agency" - a fiction that she argues, ". . . hides the institutional setting and the institutional backing of individual potency" (2003, 210). The current study of spatial experience shows that we need to be initiated - by means of and through our bodies - into enabling experiences of containment if we are to relate in existentially responsive and creative manners to a world that forms the inescapable context into which we are thrown. This argument also suggests that it is vitally incumbent upon our primary caregivers and our lawmakers to develop practices and institutions that recognize this necessity and that offer us appropriately acknowledging and supportive environments through which to develop and persist as healthy human agents in the myriad forms this may occur. ${ }^{33}$ We must respect and respond to human agency as relational and dynamic, and our existential health as inherently spatial and situational.

\section{REFERENCES}

Acredolo, Linda P., Anne Adams, and Susan W. Goodwyn. 1984. "The Role of Selfproduced Movement and Visual Tracking in Infant Spatial Orientation." Journal of Experimental Child Psychology 38: 312-27.

Ahmed, Sabeen. 2018. "From Threat To Walking Corpse: Spatial Disruption and the Phenomenology of 'Living Under Drones."' Theory Ë Event 21 (2): 382-410.

Ahmed, Sarah. 2006. "Orientations: Toward a Queer Phenomenology.” GLQ: A fournal of Lesbian and Gay Studies 12 (4): 543-74.

Arrigo, Bruce A., and Jennifer Leslie Bullock. 2008. "The Psychological Effects of Solitary Confinement on Prisoners in Supermax Units: Reviewing What We Know and Recommending What Should Change." International Fournal of Offender Therapy and Comparative Criminology 52 (6): 622-40.

Bandura, Albert. 1988. "Self-efficacy Conceptions of Anxiety." Anxiety Research 1: 77-98.

Bredlau, Susan M. 2010. "Respectful World: Merleau-Ponty and the Experience of Depth." Human Studies 33: 411-23.

\footnotetext{
${ }^{32}$ See Todres, Galvin, and Dahlberg (2007) for a discussion of why and how attending to one's spatial lifeworld matters in healthcare. They argue: "A qualitative description of human spatiality therefore includes how things appear in terms of closeness or distance, and in terms of meaning within such space. A lifeworld description that intuitively resonates with our everyday human living would include a description of how the meaning of the environing world looks or changes as circumstances change" (56). See also Todres and Galvin (2010).
} 
- 2018. The Other in Perception: A Phenomenological Account of Our Experience of Other Persons. Albany: State University of New York Press.

Carel, Havi. 2008. Illness: The Cry of the Flesh. Stocksfield, UK: Acumen Publishing.

Casey, Edward. 1991. "'The Element of Voluminousness': Depth and Place Reexamined." In Merleau-Ponty Vivant, edited by M.C. Dillon, 1-30. Albany: State University of New York Press.

— 1997. The Fate of Place: A Philosophical History. Berkeley: University of California Press.

Charmaz, Kathy. 1983. "Loss of Self: A Fundamental Form of Suffering in the Chronically Ill." Sociology of Health and Illness 2: 168-95.

Dyck, Isabel. 1995. "Hidden Geographies: The Changing Lifeworlds of Women with Multiple Sclerosis." Social Science and Medicine 40 (3): 307-20.

Febbraro, Greg A.R., and George A. Clum. 1995. "A Dimensional Analysis of Claustrophobia." Journal of Psychopathology and Behavioral Assessment 17 (4): 335-51.

Frakt, David R. J. 2011. "Mohammed Jawad and the Military Commissions of Guantánamo.” Duke Law fournal 60 (6): 1367-411.

Gehl, Raymond H. 1964. "Depression and Claustrophobia." International fournal of Psycho-Analysis 45: 312-23.

Gerardi-Caulton, Gina. 2000. "Sensitivity to Spatial Conflict and the Development of Self-Regulation in Children 24-36 Months of Age." Development Science 3 (4): 397-404.

Grassian, Stuart. 2006. "Psychiatric Effects of Solitary Confinement." Journal of Law E् Policy 22: 325-83.

Grassian, Stuart, and Nancy Friedman. 1986. "Effects of Sensory Deprivation in Psychiatric Seclusion and Solitary Confinement." International Fournal of Law and Psychiatry 8 (1): 49-65.

Guenther, Lisa. 2011. "Subjects Without a World? An Husserlian Analysis of Solitary Confinement." Human Studies 34: 257-76. 2013. Solitary Confinement: Social Death and Its Afterlives. Minneapolis: University of Minnesota Press. 
Haney, Craig. 2003. "Mental Health Issues in Long-term Solitary and 'Supermax' Confinement." Crime and Delinquency 49 (1): 124-56.

Heidegger, Martin. 1962. Being and Time. Translated by John Macquarrie and Edward Robinson. Oxford: Blackwell.

—. 1971. Poetry, Language, Thought. Translated by Albert Hofstadter. New York: Harper \& Row.

Honkasalo, Marja-Liisa. 2000. "Chronic Pain as a Posture Towards the World." Scandanavian Fournal of Psychology 41: 197-208.

Husserl, Edmund. 1989. Ideas Pertaining to a Pure Phenomenology and to a Phenomenological Philosophy, Second Book: Studies in the Phenomenology of Constitution (Ideas II). Translated by Richard Rojcewicz and André Schuwer. Boston: Kluwer.

- 1997. Thing and Space: Lectures of 1907. Translated by Richard Rojcewicz. Dordrecht: Kluwer Academic Publishers.

Jackson, Michael. 1983. Prisoners of Isolation: Solitary Confinement in Canada. Toronto: University of Toronto Press.

—. 2001. "The Psychological Effects of Administrative Segregation." Canadian Journal of Criminology 43 (1): 109-16.

Jacobson, Kirsten. 2004. "Agoraphobia and Hypochondria as Disorders of Dwelling." International Studies in Philosophy 36 (2): 31-44.

— 2006. "The Interpersonal Expression of Human Spatiality: A Phenomenological Interpretation of Anorexia Nervosa." Chiasmi International 8: 157-73.

— 2009. "A Developed Nature: A Phenomenological Account of the Experience of Home." Continental Philosophy Review 42: 355-73.

- 2010. "The Experience of Home and the Space of Citizenship." The Southern Journal of Philosophy 48 (3): 219-45.

- 2011. "Embodied Domestics, Embodied Politics: Women, Home, and Agoraphobia." Human Studies 34: 1-21. 
. 2017. "Neglecting Space: Making Sense of a Partial Loss of One's World Through a Phenomenological Account of the Spatiality of Embodiment." In Perception and It Development in Merleau-Ponty's Phenomenology, edited by Kirsten Jacobson and John Russon, 101-22. Toronto: University of Toronto Press.

Kant, Immanuel. 2003. Critique of Pure Reason. Translated by Norman Kemp Smith. New York: Palgrave Macmillan.

Kermoian, Rosanne and Joseph J. Campos. 1988. "Locomotor Experience: A Facilitator of Cognitive Development." Child Development 59: 908-17.

Krause, Sharon R. 2015. Freedom Beyond Sovereignty: Reconstructing Liberal Individualism. Chicago: University of Chicago Press.

Laing, R.D. 1969. The Divided Self. London: Penguin Books.

Leder, Drew. 1990. The Absent Body. Chicago: University of Chicago Press.

- 2004. "Imprisoned Bodies: The Life-World of the Incarcerated." Social Justice 31 (1-2): 51-66.

- 2016. The Distressed Body: Rethinking Illness, Imprisonment, and Healing. Chicago: University of Chicago Press.

Lugones, María. 2003. Pilgrimages/Peregrinajes: Theorizing Coalition Against Multiple Oppressions. New York: Rowman \& Littlefield.

Merleau-Ponty, Maurice. 1963. The Structure of Behavior. Translated by Alden Fisher. Pittsburgh: Duquesne University Press.

- 1964. The Primacy of Perception. Edited by James M. Edie. Translated by William Cobb. Evanston, IL: Northwestern University Press.

- 1968. The Visible and the Invisible. Edited by Claude Lefort. Translated by Alphonso Lingis. Evanston, IL: Northwestern University Press.

- 1993. "Eye and Mind." In The Merleau-Ponty Aesthetics Reader, edited by Galen A. Johnson. Evanston, IL: Northwestern University Press.

- 2012. Phenomenology of Perception. Translated by Donald Landes. New York: Routledge.

Morris, David. 2004. The Sense of Space. Albany: State University of New York Press. 
Moussaïd, Mehdi, Dirk Helbing, and Guy Theraulaz. 2011. "How Simple Rules Determine Pedestrian Behavior and Crowd Disasters." Proceedings of the National Academy of the Sciences (PNAS) 108 (17): 6884-88.

Noë, Alva. 2004. Action in Perception. Cambridge: Massachusetts Institute of Technology Press.

Piaget, Jean, and Bärbel Inhelder. 1956. The Child's Conception of Space. Translated by F.J. Langden and J.L. Lunzer. London: Routledge.

Profusek, Pamela J,. and David W. Rainey. 1987. "Effects of Baker-Miller Pink and Red on State Anxiety, Grip Strength, and Motor Precision." Perceptual and Motor Skills 65 (3): 941-42.

Russon, John. 2003. Human Experience: Philosophy, Neurosis, and the Elements of Everyday Life. Albany: State University of New York Press.

- 2009. Bearing Witness to Epiphany: Persons, Things, and the Nature of Erotic Life. Albany: State University of New York Press.

Russon, John, and Kirsten Jacobson. 2018. "Existential Medicine and the Intersubjective Body." In Existential Medicine: Essays on Health and Illness, edited by Kevin Aho, 191-204. Lanham, MD: Rowman \& Littlefield International.

Shafran, Roz, Richard Booth, and Stanley Rachman. 1993. "The Reduction of Claustrophobia--II. Cognitive Analyses.” Behavior Research and Therapy 31: 75-85.

Simms, Eva. 2001. "Milk and Flesh: A Phenomenological Reflection on Infancy and Coexistence." Journal of Phenomenological Psychology 32 (1): 22-40.

- 2014. "Intimacy and the Face of the Other: A Philosophical Study of Infant Institutionalization and Deprivation." Emotion, Space and Society 13: 80-86.

Slatman, Jenny, Kristin Zeiler, and Ignaas Devisch. 2016. “Can You Restore My ‘Own’ Body? A Phenomenological Analysis of Relational Autonomy." The American Journal of Bioethics 16 (8): 18-20.

Svenaeus, Fredrik. 2011. "Illness as Unhomelike Being-in-the-world: Heidegger and the Phenomenology of Medicine." Medicine, Health Care and Philosophy 14 (3): 333-43.

Thompson, Evan. 2007. Mind in Life: Biology, Phenomenology, and the Sciences of Mind. Cambridge: The Belknap Press of the Harvard University Press. 
Thompson, Evan, and Dan Zahavi. 2007. "Philosophical Issues: Phenomenology." In The Cambridge Handbook of Consciousness, edited by Philip D. Zelazo, Morris Moscovitch, and Evan Thompson, 67-88. Cambridge: Cambridge University Press.

Todres, Les, and Kathleen Galvin. 2010. "'Dwelling-mobility': An Existential Theory of Well-being." International fournal of Qualitative Studies on Health and Well-being 5 (3): DOI: 10.3402/qhw.v5i3.5444.

Todres, Les, Kathleen Galvin, and Karin Dahlberg. 2007. "Lifeworld-led Healthcare: Revisiting a Humanising Philosophy That Integrates Emerging Trends." Medicine, Health Care and Philosophy 10 (1): 53-63.

Toombs, S. Kay. 1987. "The Meaning of Illness: A Phenomenological Account of the Different Perspectives of Physician and Patient." The Fournal of Medicine and Philosophy 12 (3): 219-40.

Trigg, Dylan. 2017. Topophobia: A Phenomenology of Anxiety. London: Bloomsbury. . 2018. "From Anxiety to Nostalgia: A Heideggerian Analysis." In Existential Medicine: Essays on Health and Illness, edited by Kevin Aho, 43-57. Lanham, MD: Rowman \& Littlefield International.

Tuan, Yi-Fu. 1974. Topophilia: A Study of Environmental Perception, Attitudes, and Values. Englewood Cliffs, NJ: Prentice Hall Inc.

United States v. Jawad. 2008. Military Commission Guantánamo Bay 1: 334.

Valdez, Patricia, and Albert Mehrabian. 1994. "Effects of Color on Emotions." Fournal of Experimental Psychology 123 (4): 394-409.

Valentiner, David P., Michael J. Telch, Diana C. Petruzzi, and Molly C. Bolte. 1996. "Cognitive Mechanisms in Claustrophobia: An Examination of Reiss and McNally's Expectancy Model and Bandura's Self-efficacy Theory." Cognitive Therapy and Research 20 (6): 593-612.

Van den Berg, Jan Hendrik. 1966. The Psychology of the Sickbed. New York: Humanities Press.

1972. A Different Existence: Principles of Phenomenological Psychopathology. Pittsburgh: Duquesne University Press. 
White, Josh. 2008. "Tactic Used After it Was Banned: Detainees at Guantanamo Were Moved Often, Documents Say.” Washington Post. Accessed August 8, 2020. https://www.washingtonpost.com/wp-dyn/content/article/2008/08/07/ AR2008080703004_pf.html.

Willoughby, Roger. 2001. "The Dungeon of Thyself”: The Claustrum as Pathological Container." International fournal of Psychoanalysis 82 (5): 917-31.

Winnicott, Donald W. 1971. Playing and Reality. New York: Routledge.

Zeiler, Kristin. 2018. "On the Autós of Autonomous Decision Making: Intercorporeality, Temporality, and Enacted Normativities in Transplantation Medicine. " In Existential Medicine: Essays on Health and Illness, edited by Kevin Aho, 81-100. Lanham, MD: Rowman \& Littlefield International. 